\title{
Responsibility of States and Individuals for Mass Atrocity Crimes
}

\author{
Gentian Zyberi
}

\section{Introduction}

This chapter focuses on the practice of holding states and individuals responsible for genocide, war crimes, and crimes against humanity, referred to generally as 'mass atrocity crimes'. The International Court of Justice (ICJ or Court) has noted the separate existence of individual criminal responsibility and state responsibility as a constant feature of international law, ${ }^{1}$ and that they are governed by different legal régimes and pursue different aims. ${ }^{2}$ The purpose of this chapter is to analyse through the lens of shared responsibility ${ }^{3}$ the existing case law of international courts and tribunals concerning international responsibility for mass atrocity crimes, while also including a brief discussion of the crime of aggression. ${ }^{4}$

Gentian Zyberi is Professor of International Law and Human Rights, Norwegian Centre for Human Rights, Faculty of Law, University of Oslo. I would like to thank Andreas Zimmermann, André Nollkaemper, Ilias Plakokefalos, Semir Sali and Jessica Schechinger for their feedback on an earlier draft. Any mistakes are my own. Comments are welcome at gentian.zyberi@gmail.com. The research leading to this chapter has received funding from the European Research Council under the European Union's Seventh Framework Programme (FP7/2007-2013)/ERC grant agreement $\mathrm{n}^{\circ} 249499$, as part of the research project on Shared Responsibility in International Law (SHARES), carried out at the Amsterdam Center for International Law (ACIL) of the University of Amsterdam. All websites were last accessed in September 2016.

${ }^{1}$ Application of the Convention on the Prevention and Punishment of the Crime of Genocide (Bosnia and Herzegovina v. Serbia and Montenegro), Judgment, ICJ Reports 2007, p. 43, at p. 116, para. 173 (Application of the Genocide Convention).

${ }^{2}$ Application of the Convention on the Prevention and Punishment of the Crime of Genocide (Croatia v. Serbia), Judgment, 3 February 2015, para. 129.

${ }^{3}$ See inter alia the Introduction of this volume; P.A. Nollkaemper and D. Jacobs, 'Shared Responsibility in International Law: A Conceptual Framework' (2013) 34 MIJIL 359; P.A. Nollkaemper, 'Introduction', in P.A. Nollkaemper and Ilias Plakokefalos (eds.), Principles of Shared Responsibility in International Law: An Appraisal of the State of the Art (Cambridge University Press, 2014), p. 1, at 6-7.

${ }^{4}$ These four categories of serious crimes are internationally recognised and fall under the jurisdiction of the International Criminal Court (ICC). Besides triggering individual criminal responsibility, these crimes also engage state responsibility. For our purposes here 'shared responsibility' implies that both states and individuals are responsible for their contribution to a single harmful outcome (and the contributions cannot causally be attributed to individual actors), see ibid. 
Instances of shared responsibility can be divided into two categories. The first category consists of shared responsibility for mass atrocities caused by joint or concerted action. This can involve concerted action of two or more states; of a state and political or military leaders of armed groups in another state; or of a plurality of individuals. The second category consists of cases when there is no concerted action, e.g. when mass atrocities are committed in a state and other states fail in their responsibility to prevent them, such as the situation in Syria. This chapter discusses both categories, though there are obvious differences in terms of legal principles and processes.

Evidently, responsibility for mass atrocities cannot be seen solely as a matter of state responsibility or individual criminal responsibility, as international organisations or other nonstate actors might be involved at different degrees in what could more aptly be described as processes of collective wrongdoing. ${ }^{5}$ However, the responsibility of international organisations or other non-state actors is not addressed here. ${ }^{6}$

First, the chapter provides an overview of international efforts to address mass atrocities through ensuring individual and state responsibility (section 2). Subsequently, the primary (section 3) and secondary rules (section 4), as well as relevant legal processes concerning state responsibility and individual criminal responsibility are discussed in more detail (section 5).

\section{Attempts to hold states and individuals responsible for mass atrocities}

The international response to crimes committed in armed conflicts, as far as individual criminal responsibility and state responsibility are concerned, has varied widely from neglect to

\footnotetext{
${ }^{5}$ See generally P.A. Nollkaemper and H. van der Wilt (eds.), System Criminality in International Law (Cambridge University Press, 2009); T. Isaacs and R. Vernon (eds.), Accountability for Collective Wrongdoing (Cambridge University Press, 2011).

${ }^{6}$ For more information on this issue see inter alia the International Law Commission (ILC) Articles on the Responsibility of International Organizations, ILC Report on the work of its sixty-third session, UNGAOR 66th Sess., Supp. No. 10, UN Doc. A/66/10 (2011) (ARIO). On the responsibility of non-state actors see generally chapters 22 (P. Klein, 'The Attribution of Acts to International Organizations'); 23.1 (C. Tomuschat, 'The Responsibility of Other Entities - Private Individuals'); 23.2 (G. Cahin, 'The Responsibility of Other Entities Armed Bands and Criminal Groups'); and 23.3 (A.-K. Lindblom, 'The Responsibility of Other Entities - NonGovernmental Organizations'), in J. Crawford, A. Pellet and S. Olleson (eds.), The Law of International Responsibility (Oxford University Press, 2010), pp. 297-354.
} 
requiring and exacting responsibility of some sort. ${ }^{7}$ That response has fluctuated depending on the political willingness of the main political actors and the capacity of international law norms and mechanisms available. Over time international justice has shifted towards individualising responsibility and punishment, through investigating and prosecuting a limited number of persons, focusing mainly on high-level perpetrators bearing the greatest responsibility. At the same time, state responsibility remains relevant, in part because atrocities may be attributable to states, but primarily because states have the obligation to protect their populations from mass atrocities. Moreover, mass atrocity crimes generally require at least some minimum involvement and use of state structures or their acquiescence therein. Situations of mass violence more often than not involve systemic criminality against certain segments of the population. ${ }^{8}$

In relation to the atrocities committed in Cambodia; the former Yugoslavia; Rwanda and more generally in the Great Lakes region; Sierra Leone; Sudan (Darfur); and Syria, it seems that both states and individuals shared responsibility. The international response to these events has varied in terms of accountability mechanisms established, the focus on individual or state responsibility, and the achieved degree of accountability.

The international response with regard to individual responsibility for mass crimes committed during the First and the Second World War differed quite considerably. The German leadership largely escaped responsibility for crimes committed during the First World War (WW1), whereas for the Second World War (WW2) a limited number of 24 senior civilian and military leaders was charged and tried by the International Military Tribunal in Nuremberg (Nuremberg Tribunal), and about 300 other individuals were tried domestically on the basis of the Control Council 10 Law. ${ }^{9}$ A small number of senior Japanese officials were tried by the

\footnotetext{
${ }^{7}$ See inter alia N.H.B. Jørgensen, The Responsibility of States for International Crimes (Oxford University Press, 2003); B.I. Bonafè, The Relationship Between State and Individual Responsibility for International Crimes (Leiden: Brill, 2009); A. Ollivier, 'International Criminal Responsibility of the State', in Crawford, Pellet and Olleson (eds.), The Law of International Responsibility, ibid., p. 703.

${ }^{8}$ Nollkaemper defines 'system criminality' as a situation where collective entities order or encourage international crimes to be committed, or permit or tolerate the committing of international crimes. See P.A. Nollkaemper, 'Introduction', in Nollkaemper and van der Wilt (eds.), System Criminality in International Law, n. 5, p. 1, at 16.

${ }^{9}$ See Charter of the International Military Tribunal (1945), 82 UNTS 279; Control Council No. 10, in Official Gazette of the Control Council for Germany, No. 3, Berlin, 31 January 1946; Trial of the Major War Criminals before the International Military Tribunal, Nuremberg, 14 November 1945 - 1 October 1946 (Nuremberg: Germany, 1947), 42 volumes; The Avalon Project, Yale Law School (Lillian Goldman Law Library), available at
} 
Military Tribunal for the Far East (Tokyo Tribunal). From the perspective of state responsibility it must be noted that losing states in WW2 had to pay reparation for the crimes committed and the material damage caused. ${ }^{10}$ Eventually, for WW2 a higher degree of accountability was achieved in terms of both state responsibility and individual criminal responsibility for mass atrocity crimes.

The armed conflicts in the former Yugoslavia in the 1990s also have given rise to complex and lengthy legal processes, involving both individual and state responsibility for mass atrocities. ${ }^{11}$ The International Criminal Tribunal for the former Yugoslavia (ICTY) has indicted 161 persons, including a sitting head of state, for crimes committed during the armed conflicts which accompanied the break-up of the former Yugoslavia. ${ }^{12}$ Hundreds more have been prosecuted domestically in Bosnia, Croatia, Serbia and Kosovo, but also in third countries, including Germany, France, Canada, Norway and so on. ${ }^{13}$ In terms of state responsibility, the ICJ found Serbia responsible for failing its duty to prevent the genocide in Srebrenica, Bosnia. ${ }^{14}$ The ICJ rejected, however, a claim brought by Croatia against Serbia and a counterclaim by Serbia against Croatia, since it did not find any of the acts committed capable of being

http://avalon.law.yale.edu/subject_menus/imt.asp. See also Memorandum by the UN Secretary-General, 'The Charter and the Judgment of the Nürnberg Tribunal: History and Analysis', UN Doc. A/CN.4/5 (1949).

${ }^{10}$ Germany had to pay reparations for WW1 on the basis of the Treaty of Versailles, especially Part VIII on Reparations (Articles 231-247) and the 1953 London Agreement on German External Debts. Germany finalised the payment of reparations for WW1 in October 2010. A number of states, including Germany, Italy, Japan, Finland, Hungary, Bulgaria and Romania had to pay reparations for crimes committed during WW2, based on the basis of the 1945 Potsdam conference and the 1947 Paris Peace Treaties.

${ }^{11}$ See also the Final Report of the Commission of Experts Established Pursuant to Security Council Resolution UN Doc. S/RES/780 (1992); UN Doc. S/RES/674 (27 May 1994) concerning grave breaches of the 1949 Geneva Conventions, n. 35, and other violations of international humanitarian law committed in the territory of the former Yugoslavia.

${ }^{12}$ For more information see 'Key figures of the cases' at http://icty.org/sections/TheCases/KeyFiguresoftheCases.

${ }^{13}$ See inter alia 'Development of the Local Judiciaries' at www.icty.org/sid/10462. In Bosnia and Herzegovina these crimes are tried by the Section for War Crimes within the State Court; in Serbia by the War Crimes Chamber of the Belgrade District Court; in Croatia by chambers dealing specifically with war crimes cases within the County Courts in Zagreb, Osijek, Rijeka and Split; in Kosovo by international or mixed trial panels of UNMIK and now of EULEX. See also M.A. Drumbl, Atrocity, Punishment, and International Law (Cambridge University Press, 2007), especially pp. 68-122.

${ }^{14}$ Application of the Genocide Convention, n. 1, paras. 433-438 and 439-450. 
characterised as genocide. ${ }^{15}$ The ten cases brought before the ICJ by Serbia in April 1999 against North Atlantic Treaty Organization (NATO) countries for their military intervention in Kosovo were dismissed for lack of jurisdiction. ${ }^{16}$ Thus, although 12 cases have been brought before the ICJ claiming serious violations of international law during the armed conflicts in the former Yugoslavia, the Court has been able to make specific findings concerning state responsibility for violation of the Genocide Convention in only one case.

Many serious crimes have been committed in the Great Lakes region, with the 1994 genocide in Rwanda being the most gruesome event of the late $20^{\text {th }}$ century. The International Criminal Tribunal for Rwanda (ICTR) has indicted 93 individuals for the mass atrocity crimes in Rwanda, where about 800,000 persons were killed in a few months. ${ }^{17}$ About a million individuals have been tried domestically by Rwandan courts starting from December 1996, and the customary gacaca trials operating from 2001 to $2012 .{ }^{18}$ So far, no case concerning state responsibility has been brought in relation to mass atrocities committed in 1994 in Rwanda. In June 1999, the DRC brought three cases before the ICJ against neighbouring states, namely Uganda, Rwanda and Burundi for violations of human rights and humanitarian law. ${ }^{19}$ In December 2005, the ICJ found Uganda responsible for serious violations of humanitarian law

\footnotetext{
${ }^{15}$ See Application of the Convention on the Prevention and Punishment of the Crime of Genocide (Croatia v. Serbia), n. 2, respectively paras. 441 and 522, and the operative clause in para. 524.

${ }^{16}$ For more information on these cases see 'List of All Cases' at www.icj-cij.org. The cases against the US and Spain were removed from the List in June 1999; the cases against the UK, Portugal, the Netherlands, Italy, Germany, France, Canada and Belgium were dismissed for lack of jurisdiction in December 2004.

${ }^{17}$ The ICTR official website notes 77 completed cases, 6 cases on appeal and nine fugitives at large. For more information on the cases tried before the ICTR see http://www.unictr.org/en/cases/key-figures-cases. See also the Final Report of the Commission of Experts Established Pursuant to Security Council Resolution 935 (1994), UN Doc. S/1994/1405 (9 December 1994).

18 See generally 'Background Information on the Justice and Reconciliation Process in Rwanda' at www.un.org/en/preventgenocide/rwanda/about/bgjustice.shtml. For a detailed discussion of the gacaca model of justice see inter alia P. Clark, The Gacaca Courts, Post-Genocide Justice and Reconciliation in Rwanda: Justice Without Lawyers (Cambridge University Press, 2010). See also Human Rights Watch, 'Justice Compromised: The Legacy of Rwanda's Community-Based Gacaca Courts', 31 May 2011, available at www.hrw.org/reports/2011/05/31/justice-compromised.

${ }^{19}$ The case brought by the DRC against Burundi was discontinued in 2001, whereas the case against Rwanda was dismissed by the ICJ for lack of jurisdiction in 2006.
} 
and human rights committed by its military forces in the eastern part of the DRC. ${ }^{20}$ Among others, these cases highlight inter-ethnic tensions which have spread across different neighbouring countries in the Great Lakes region and which have involved several states and leading state officials. Currently, the Office of the Prosecutor of the International Criminal Court (OTP/ICC) is investigating nine situations, namely in Uganda; the Democratic Republic of Congo (DRC); the Central African Republic (I and II); Sudan (Darfur); Kenya; Libya; Côte d'Ivoire; and Mali, and has started 22 cases. $^{21}$ At the same time, the ICC-OPT has carried out preliminary examinations in relation to the situation in a number of other states, in order to determine whether a crime which falls under ICC jurisdiction has been, or is being, committed. $^{22}$

While the former President of Liberia, Charles Ghankay Taylor, was tried and sentenced to 50 years imprisonment by the Special Court for Sierra Leone (SCSL) for crimes committed in Sierra Leone, ${ }^{23}$ Liberia has incurred no responsibility for its alleged involvement in the Sierra Leonean civil war. No formal steps towards ensuring individual or state responsibility have been taken with regard to the situation in Syria, ${ }^{24}$ although the UN has reported that the death toll from this conflict has risen to 191,369 persons. ${ }^{25}$ The situations in Cambodia; the former Yugoslavia; Sudan (Darfur) and South Sudan; Syria; and other countries demonstrate that when the state itself is responsible for grave violations of human rights and humanitarian law, state

\footnotetext{
${ }^{20}$ Armed Activities on the Territory of the Congo (Democratic Republic of the Congo v. Uganda), Judgment, ICJ Reports 2005, p. 168, at p. 280, para. 345(3). Reparations due to the DRC by Uganda for violations of human rights and humanitarian law still have to be determined by the ICJ, more than nine years after the judgment on the merits.

${ }^{21}$ For more information see www.icc-cpi.int/EN_Menus/ICC/Pages/default.aspx under 'Situations and Cases'. Five of these situations involve self-referrals by states, namely Uganda, the Democratic Republic of Congo (DRC), Mali and the Central African Republic (I and II); two situations involve referrals by the Security Council, namely Sudan (Darfur) and Libya; and two situations involve investigations opened by the OTP/ICC proprio motu, namely Kenya and Côte d'Ivoire.

${ }^{22}$ ICC-OTP, Policy Paper on Preliminary Examinations (November 2013), available at http://www.icc-cpi.int.

${ }^{23}$ See Prosecutor v. Charles Ghankay Taylor, Case No. SCSL-03-01-A, Appeals Judgment, 26 September 2013 (Taylor Appeals Judgment).

${ }^{24}$ The Independent International Commission of Inquiry on the Syrian Arab Republic, established on 22 August 2011 by the Human Rights Council through resolution S-17/1, with a mandate to investigate all alleged violations of international human rights law since March 2011 in the Syrian Arab Republic, has issued a number of reports.

${ }^{25}$ For updated information on the humanitarian situation in Syria see http://www.unocha.org/syria.
} 
responsibility is difficult to pursue. In addition, the expectation that a state would be able to prosecute or surrender its own leaders while they are in power is unrealistic.

These examples paint a fairly complex picture about legal processes concerned with adjudicating individual criminal responsibility and state responsibility for mass atrocities. As Nollkaemper has pointed out, concurrence between state responsibility and individual responsibility can be relevant both from a practical and from a theoretical perspective. ${ }^{26}$ Thus, findings pertaining to individual responsibility may influence subsequent determinations on state responsibility and also give rise to the question of whether the principles of state responsibility in case of concurrence differ from 'ordinary' cases of state responsibility. ${ }^{27}$ In principle, several of the above situations could have led to a finding of shared responsibility between a state and individuals, and some cases (including WW1 and the genocide in Srebrenica) indeed can be qualified as such. This particular area of international law is one of the rare areas where shared responsibility between states and individuals under international law can indeed occur. However, this brief overview does not seem to show any regularity or clear pattern in the way international responsibility for mass atrocities has been handled, either for mass atrocities occurring within a state, or for those caused as a result of an international armed conflict. Notably though, over the last two decades the focus has shifted considerably on individual criminal responsibility, with state responsibility getting relatively little attention.

\section{Obligations relating to the prohibition of mass atrocity crimes}

The obligations that prescribe the conduct required by individuals and states concerning preventing or stopping, as well as punishing those responsible for, mass atrocities have been included in several international treaties, and have also become part of customary international law. ${ }^{28}$ In principle, these obligations can provide the basis for responsibility of both states and individuals.

\footnotetext{
${ }^{26}$ P.A. Nollkaemper, 'Concurrence between Individual Responsibility and State Responsibility in International Law' (2003) 52 ICLQ 615, at 615.

${ }^{27}$ Ibid.

${ }^{28}$ Some of the most important international instruments which prohibit serious violations of human rights and humanitarian law are the 1948 Genocide Convention, n. 40; the 1949 Geneva Conventions, n. 35; the 1977 Additional Protocols to the Geneva Conventions, n. 36; the 1984 Convention against Torture, n. 46; the Statutes of the two ad hoc tribunals for the former Yugoslavia and Rwanda established by the UN Security Council respectively in 1993 (Resolution 827 of 25 May 1993) and 1994 (Resolution 955 of 8 November 1994); and the ICC Statute, n. 52. See also J.-M. Henckaerts and L. Doswald-Beck, Customary International Humanitarian Law:
} 
However, while these norms overlap in terms of substance, the scope of obligations international law imposes on individuals and on states differs considerably. While individuals have the duty to abstain from inciting, planning, aiding and abetting or otherwise participating in committing mass atrocity crimes, states have a positive obligation to protect their populations from widespread and serious violations of human rights and humanitarian law. ${ }^{29}$ In addition, states have a duty to investigate and prosecute perpetrators of genocide, war crimes, and crimes against humanity and to cooperate with international tribunals established to investigate and prosecute alleged perpetrators of such crimes. ${ }^{30}$

Volume I: Rules; Volume II: Practice - Parts 1 and 2 (Cambridge University Press, 2005); the study is available at www.icrc.org/customary-ihl/eng/docs/home.

${ }^{29}$ This obligation, enshrined in the 'responsibility to protect' doctrine (RtoP), has a strong basis in international human rights and humanitarian law. The UN endorsed the RtoP doctrine in General Assembly Resolution, 'World Summit Outcome Document', UN Doc. A/Res/60/1 (24 October 2005), paras. 138-140. The UN Secretary-General has prepared several explanatory reports, including 'Implementing the Responsibility to Protect', UN Doc. A/63/677 (12 January 2009); 'Early Warning, Assessment and the Responsibility to Protect', UN Doc. A/64/864 (14 July 2010); 'The Role of Regional and Subregional Arrangements in Implementing the Responsibility to Protect', UN Doc. A/65/877-S/2011/393 (28 June 2011); 'Responsibility to Protect: Timely and Decisive Response', UN Doc. A/66/874-S/2012/578 (25 July 2012); 'Responsibility to Protect: State Responsibility and Prevention', UN Doc. A/67/929-S/2013/399 (9 July 2013); 'Fulfilling Our Collective Responsibility: International Assistance and the Responsibility to Protect', UN Doc. A/68/947-S/2014/449 (11 July 2014). For a more detailed discussion see inter alia G. Evans, The Responsibility to Protect: Ending Mass Atrocity Crimes Once and for All (Washington D.C.: Brookings Institution Press, 2008); A. Orford, International Authority and the Responsibility to Protect (Cambridge University Press, 2011); J. Genser and I. Cotler (eds.), The Responsibility to Protect: The Promise of Stopping Mass Atrocities in Our Time (Oxford University Press, 2011); J. Hoffmann and P.A. Nollkaemper (eds.), Responsibility to Protect: From Principle to Practice (Amsterdam University Press, 2012); G. Zyberi (ed.), An Institutional Approach to the Responsibility to Protect (Cambridge University Press, 2013); P. Hilpold, The Responsibility to Protect (R2P): A New Paradigm of International Law? (Leiden: Martinus Nijhoff Publishers, 2014); D. Fiott and J. Koops (eds.), The Responsibility to Protect and the Third Pillar: Legitimacy and Operationalization (London: Palgrave Macmillan, 2014); A.J. Bellamy, The Responsibility to Protect: A Defence (Oxford University Press, 2014).

${ }^{30}$ See inter alia the Statutes and the case law of the Nuremberg and the Far East Tribunal; the International Law Commission's Nuremberg Principles (29 July 1950); the 1948 Genocide Convention, n. 40; the 1949 Geneva Conventions, n. 35; the 1984 Convention Against Torture, n. 46; the Statutes and the case law of the ICTY, the ICTR and the ICC; and the Statutes and the case law of a number of hybrid criminal courts. See also Application of the Genocide Convention, n. 1, paras. 439-50; Questions Relating to the Obligation to Prosecute or Extradite (Belgium v. Senegal), Judgment, ICJ Reports 2012, p. 422, at paras. 94-95 and 118-121 (Obligation to Prosecute or Extradite). See also Final Report of the International Law Commission, 'The obligation to extradite or prosecute 
The prohibitions of aggression, genocide, war crimes, and crimes against humanity constitute a commonly shared interest of the international community. ${ }^{31}$ Their codification in several international treaties and crystallisation into rules of customary international law is relevant for shared responsibility, as it means that both for individuals and for states the obligations imposed are of a universal character. Hence, no situation is likely to arise where one actor contributing to crimes is bound by a particular norm, and another is not. International courts have acknowledged that certain international legal norms, such as the prohibition of genocide, have attained the status of peremptory norms of international law or jus cogens norms. ${ }^{32}$ In the Obligation to Prosecute or Extradite case, the ICJ has held that the prohibition of torture is also part of customary international law and that it has become a jus cogens norm. ${ }^{33}$ Additionally, the ICJ has emphasised that, because a great many rules of humanitarian law applicable in armed conflict are so fundamental to the respect of the human person and 'elementary considerations of humanity', these fundamental rules are to be observed by all states whether or not they have ratified the conventions that contain them, because they constitute intransgressible principles of international customary law. ${ }^{34}$ These fundamental rules include the grave breaches system established by the 1949 Geneva Conventions ${ }^{35}$ and the 1977

(aut dedere aut judicare)', ILC Yearbook 2014/II(2). For a detailed discussion see inter alia A. Seibert-Fohr, Prosecuting Serious Human Rights Violations (Oxford University Press, 2009).

${ }^{31}$ On the concept of community interests see inter alia B. Simma, 'From Bilateralism to Community Interest in International Law' (1994) 250 RCADI 217; S. Villalpando, 'The Legal Dimension of the International Community: How Community Interests Are Protected in International Law' (2010) 21 EJIL 387; A. Zimmermann, 'The Obligation to Prevent Genocide: Towards a General Responsibility to Protect?, in U. Fastenrath, R. Geiger, D.-E. Khan, A. Paulus, S. von Schorlemer and C. Vedder (eds.), From Bilateralism to Community Interest: Essays in Honour of Judge Bruno Simma (Oxford University Press, 2011), p. 629.

${ }^{32}$ Reservations to the Convention on the Prevention and Punishment of the Crime of Genocide, Advisory Opinion, ICJ Reports 1951, p. 15, at p. 23; Armed Activities on the Territory of the Congo (New Application: 2002) (Democratic Republic of the Congo v. Rwanda), Jurisdiction and Admissibility, ICJ Reports 2006, p. 6, at 32, para. 64; Application of the Genocide Convention, n. 1, pp. 110-111, para. 161.

${ }^{33}$ Obligation to Prosecute or Extradite, n. 30, para. 99.

${ }^{34}$ Legality of the Threat or Use of Nuclear Weapons, Advisory Opinion, ICJ Reports 1996, p. 226, p. 257, para. 79.

${ }^{35}$ Geneva Convention for the Amelioration of the Condition of the Wounded and Sick in Armed Forces in the Field, Geneva, 12 August 1949, in force 21 October 1950, 75 UNTS 31; Geneva Convention for the Amelioration of the Condition of the Wounded, Sick and Shipwrecked Members of Armed Forces at Sea, Geneva, 12 August 1949, in force 21 October 1950, 75 UNTS 85; Geneva Convention relative to the Treatment of Prisoners of War, 
Additional Protocol I, ${ }^{36}$ as well as more generally serious violations of laws and customs of war which have a basis in customary international humanitarian law. The ICTY has held that most norms of international humanitarian law, in particular those prohibiting war crimes, crimes against humanity and genocide, are also peremptory norms of international law or jus cogens, i.e. of a non-derogable and overriding character. ${ }^{37}$ In relation to obligations imposed by these international legal norms, it can be said that in principle both states and individuals are bound by them. A number of authors list among peremptory norms the prohibition of aggression, the prohibition of slavery and slave trade, racial discrimination, torture, collective punishments, access to justice, and the right to a fair trial. ${ }^{38}$ While opinions differ, it is obvious that the list of jus cogens norms has expanded considerably over the last decades, well beyond the prohibition of genocide and of torture.

It is relevant to point out that, as the ICJ has noted, 'even if two norms belonging to two sources of international law appear identical in content, and even if the States in question are bound by these rules both on the level of treaty-law and on that of customary international law, these norms retain a separate existence'. ${ }^{39}$ For our purpose this means that, where customary international law applies, a state's obligation to prevent mass atrocity crimes exists even absent

Geneva, 12 August 1949, in force 21 October 1950, 75 UNTS 135; Geneva Convention relative to the Protection of Civilian Persons in Time of War, Geneva, 12 August 1949, in force 21 October 1950, 75 UNTS 287 (1949 Geneva Conventions).

${ }^{36}$ International Committee of the Red Cross (ICRC), Protocol Additional to the Geneva Conventions of 12 August 1949, and relating to the Protection of Victims of International Armed Conflicts (Protocol I), Geneva, 8 June 1977, in force 7 December 1978, 1125 UNTS 3 (Additional Protocol I); ICRC, Protocol Additional to the Geneva Conventions of 12 August 1949, and relating to the Protection of Victims of Non-International Armed Conflicts (Protocol II), Geneva, 8 June 1977, in force 7 December 1978, 1125 UNTS 609 (Additional Protocol II).

${ }^{37}$ Prosecutor v. Kupreškić, ICTY Case No. 95-16-T, Judgment of 14 January 2000, para. 520.

${ }^{38}$ See inter alia M. Ragazzi, The Concept of International Obligations Erga Omnes (Oxford University Press, 2000); C. Tomuschat and J. M. Thouvenin (eds.), The Fundamental Rules of the International Legal Order: Jus Cogens and Obligations Erga Omnes (Leiden: Martinus Nijhoff Publishers, 2006); A. Orakhelashvili, Peremptory Norms in International Law (Oxford University Press, 2008); J. Vidmar, 'Norm Conflicts and Hierarchy in International Law: Towards a Vertical International Legal System?' in E. De Wet and J. Vidmar (eds.), Hierarchy in International Law: The Place of Human Rights (Oxford University Press, 2012), p. 13; A. Cassese, 'For an Enhanced Role of Jus Cogens' in A. Cassese (ed.), Realizing Utopia: The Future of International Law (Oxford University Press, 2012), p. 158.

${ }^{33}$ Military and Paramilitary Activities in and against Nicaragua, (Nicaragua v. United States of America), Merits, ICJ Reports 1986, p. 14, at p. 95, para. 178 (Nicaragua). 
a formal ratification of relevant international instruments, such as the 1948 Genocide Convention. ${ }^{40}$

With regard to responsibility for war crimes it should be noted that the 1949 Geneva Conventions enjoy universal ratification, and principles concerning the protection of civilians and non-combatants more generally have become part of customary international humanitarian law. ${ }^{41}$ As to crimes against humanity the situation is different, since there is no international treaty covering them as of yet. ${ }^{42}$ For that reason, relevant rights and duties concerning crimes against humanity are mainly based on customary international law and the Statutes of a number of international criminal courts and tribunals. The primary rules concerning the prohibition of genocide, war crimes and crimes against humanity, laid down in the provisions of a number of relevant international treaties and customary international law norms, allow for shared responsibility between states and individuals.

The above obligations do not only contain obligations for individual persons and states involved, but also for third states and, more generally, the organised international community of states. This can further extend the number of issues and actors subject to a shared responsibility. ${ }^{43}$ Under treaties such as the 1948 Genocide Convention, the four 1949 Geneva Conventions ${ }^{44}$ and their two Additional Protocols of $1977,{ }^{45}$ and the 1984 Convention against Torture, ${ }^{46}$ a state bears primary responsibility for protecting its population from mass atrocities. ${ }^{47}$ At the same time, third states and the organised international community of states

\footnotetext{
${ }^{40}$ Convention on the Prevention and Punishment of the Crime of Genocide, Paris, 9 December 1948, in force 12 January 1951, 78 UNTS 277 (Genocide Convention).

${ }^{41}$ See Henckaerts and Doswald-Beck, Customary International Humanitarian Law, n. 28. See especially Rule 1 on the obligation of the parties to a conflict to distinguish at all times between civilians and combatants.

${ }^{42}$ See also L.N. Sadat (ed.), Forging a Convention for Crimes Against Humanity (Cambridge University Press, 2011). During its 65th session in 2013 the ILC decided to include in its long-term programme of work the topic 'Crimes against humanity', UN Doc. A/68/10 (2013), chapter XII, section A.2 and annex B.

${ }^{43}$ See generally Nollkaemper and Plakokefalos (eds.), Principles of Shared Responsibility in International Law, n. 3. See also J. Crawford, State Responsibility: The General Part (Cambridge University Press, 2013), especially pp. $325-361$.

${ }^{44}$ Geneva Conventions, n. 35.

${ }^{45}$ See n. 36

${ }^{46}$ Convention Against Torture and Other Cruel, Inhumane or Degrading Treatment or Punishment, New York, 10 December 1984, in force 26 June 1987, 1465 UNTS 85 (Convention against Torture).

${ }^{47}$ Article I of the 1948 Genocide Convention, n. 40, establishes the obligation of states to prevent and punish the crime of genocide. Common Article 1 of the 1949 Geneva Conventions, n. 35, establishes the obligation of states
} 
are expected to take action in accordance with international law when a state manifestly fails in its responsibility to protect its population from mass atrocities. ${ }^{48}$ The ' responsibilities' (in terms of obligations) of third states and the international community have been articulated in in the 2009-2014 Secretary-General reports on the responsibility to protect (RtoP). ${ }^{49}$ The July 2014 report states that the international community has a collective responsibility to help to protect populations from acts that have been defined as 'international crimes' ${ }^{50}$ However, while third states cannot remain indifferent to the commission of mass atrocity crimes, it is not entirely clear when a third state can be considered complicit in the commitment of such crimes.

\section{Rules on international responsibility for mass atrocity crimes}

In those cases where states and individuals are subject to the same norms, in principle both can be responsible. Breaches of legal obligations by states and by individuals can trigger their international responsibility. The secondary rules of state responsibility stipulate the general conditions under international law for the state to be considered responsible for wrongful acts or omissions, and the legal consequences which flow therefrom. ${ }^{51}$ Similarly, the secondary rules of individual criminal responsibility are the general conditions under international law for an individual to be considered responsible for wrongful acts or omissions, and the legal consequences which flow therefrom.

However, the regimes are formally separate. International law has distinct regimes of responsibility for state and individual responsibility. A number of 'saving clauses' included in relevant international instruments separate individual criminal responsibility from state responsibility. Thus, Article 25(4) of the ICC Statute provides that: 'No provision in this Statute relating to individual criminal responsibility shall affect the responsibility of States under international law.' 52 This Article is based on Article 4 of the 1996 International Law

\footnotetext{
to respect and ensure respect for international humanitarian law in all circumstances. Article 2(1) of the Convention against Torture, ibid., establishes the obligation of each state party to take effective legislative, administrative, judicial or other measures to prevent acts of torture in any territory under its jurisdiction.

${ }^{48}$ See paras. 138-139 of the 2005 World Summit Outcome Document, n. 29. See also generally n. 29.

${ }^{49}$ See n. 29.

50 'Fulfilling Our Collective Responsibility, n. 29, para. 2.

${ }^{51}$ Commentary to the Articles on Responsibility of States for Internationally Wrongful Acts, ILC Yearbook 2001/II(2) (ARSIWA Commentary).

${ }^{52}$ Rome Statute of the International Criminal Court, Rome, 17 July 1998, in force 1 July 2002, 2187 UNTS 3 (ICC Statute).
} 
Commission (ILC)'s Draft Code of Crimes against the Peace and Security of Mankind which states that, '[t]he fact that the present Code provides for the responsibility of individuals for crimes against the peace and security of mankind is without prejudice to any question of the responsibility of States under international law.' ${ }^{53}$ Also Article 58 of the Articles on Responsibility of States for Internationally Wrongful Acts (ARSIWA) ${ }^{54}$ provides that, 'these articles are without prejudice to any question of the individual responsibility under international law of any person acting on behalf of a State'. While conceptually separate, the secondary rules concerning individual criminal responsibility and state responsibility display a number of similarities and differences.

\subsection{Differences in the nature of responsibility}

The secondary rules concerned with the enforcement of international norms imposing obligations on both states and individuals differ in several important aspects, including enforcement mechanisms, legal proceedings, rules of attribution of responsibility, and consequences arising therefrom. Perhaps the most notable difference is that the principles of state responsibility are comparably less attuned to the specific nature of crimes. The classic theory of international responsibility, built upon the reciprocity of rights and obligations of states, can prove rather inadequate in addressing cases where collective values such as peace, or basic human rights need to be protected. The intuition that a different regime of state responsibility existed in these cases led the ILC to propose the concept of 'state crimes', in draft Article 19 of its codification of state responsibility. ${ }^{55}$ The whole saga that ensued, and which finally led to the adoption of Articles 40, 41, and 48 of the final 2001 ARSIWA, clarified that this separate regime was not to be 'criminal' in nature, and also demonstrated that there was quasi-unanimous adherence to the idea that the injury to the interests of the international

\footnotetext{
${ }^{53}$ Draft Code of Crimes against the Peace and Security of Mankind, ILC Yearbook 1996/II/(2), at 23.

${ }^{54}$ Articles on Responsibility of States for Internationally Wrongful Acts, ILC Yearbook 2001/II(2) (ARSIWA).

${ }^{55}$ See ILC Yearbook 1976/II(I), paras. 95-122. Under draft Article 19(2), an 'international crime' was defined as '[a]n internationally wrongful act which results from the breach by a State of an international obligation so essential for the protection of fundamental interests of the international community that its breach is recognized as a crime by that community as a whole', thus making a dual relationship with the international community both substantively (its fundamental interests being harmed) and formally (the community should recognise the act as a crime). Draft Article 19(3) gave a series of examples of such crimes, which included aggression, the establishment or maintenance by force of colonial domination, slavery, genocide, apartheid, and massive pollution of the atmosphere or of the seas.
} 
community as a whole implies special consequences ${ }^{56}$ Consequently, Villalpando argues that the 25-year-long discussion on state crimes resulted in the abandonment of that notion, and the importation of the concepts of jus cogens and obligations erga omnes to the realm of international responsibility. ${ }^{57}$ Instead of 'abandonment', however, the solution finally adopted by the ILC can also be seen as some sort of a compromise which attaches 'special' consequences to the crimes of aggression, genocide, war crimes, and crimes against humanity. ${ }^{58}$

The ARSIWA identify two separate regimes of responsibility towards the international community as a whole. First, a general regime applicable in the event of a breach of any obligation erga omnes, by which states other than the injured state may claim the cessation of the wrongful act and assurances and guarantees of non-repetition, as well as the performance of the obligation of reparation in the interest of the injured state or of the beneficiaries of the obligation breached. ${ }^{59}$ Second, an aggravated regime applicable only to serious breaches of obligations under peremptory norms of general international law, under which all states have the obligation to cooperate to bring the breach to an end through lawful means, not to recognise as lawful the ensuing situation, and not to render aid or assistance in maintaining it. ${ }^{60}$ However, none of these regimes is generally understood as entailing a 'criminal' responsibility on the part of the state. The main aim of these responsibility regimes is to protect commonly agreed community interests through a system of collective action.

The rules of attribution of responsibility and the legal consequences arising from such grave breaches of obligations owed to the international community as a whole thus are specific for states and for individuals. ${ }^{61}$ State responsibility has primarily a civil character related to the

\footnotetext{
${ }^{56}$ Villalpando, 'The Legal Dimension of the International Community', n. 31, at 405-406.

${ }^{57}$ Ibid., at 409.

${ }^{58}$ E.A. Wyler and L.A. Castellanos-Jankiewicz, 'Serious Breaches of Peremptory Norms', in Nollkaemper and Plakokefalos (eds.), Principles of Shared Responsibility in International Law, n. 3, p. 284.

${ }^{59}$ See Article 48 ARSIWA, n. 54.

${ }^{60}$ Articles 40 and 41 of the ARSIWA, ibid.

${ }^{61}$ See inter alia chapters 18 (L. Condorelli and C. Kress, 'The Rules of Attribution: General Considerations'); 19.1 (D. Momtaz, 'Attribution of Conduct to the State - State Organs and Entities Empowered to Exercise Elements of Governmental Authority'); 19.2 (G. Cahin, 'Attribution of Conduct to the State - Insurrectional Movements'); 19.3 (O. de Frouville, 'Attribution of Conduct to the State - Private Individuals'); and 20 (C. Dominicé, 'Attribution of Conduct to Multiple States and the Implication of a State in the Act of Another State') in Crawford, Pellet and Olleson (eds.), The Law of International Responsibility, n. 6, pp. 221-90.
} 
obligation to make reparations for wrongful acts attributable to it. ${ }^{62}$ Individual criminal responsibility is primarily related to criminal punishment where guilt needs to be proven beyond a reasonable doubt. Under Article 75(2) of the ICC Statute, it is possible for the Court to make an order directly against a convicted person specifying appropriate reparations to, or in respect of, victims, including restitution, compensation and rehabilitation.

\subsection{Situations concerning shared responsibility for mass atrocities}

The situations concerning shared responsibility for mass atrocities can be categorised as follows. First, situations where an international court has determined the individual criminal responsibility of a person, whose acts can also be attributed to a state, but no legal proceedings can be, or have been, brought forward to determine state responsibility (e.g. the decision in the Taylor case by the SCSL, and the potential responsibility of Liberia for the civil war in Sierra Leone).

Second, situations where an international court has determined the criminal responsibility of an individual whose acts cannot be attributed to a state, but where the state may incur responsibility based on other grounds, for example complicity, or lack of due diligence (e.g. where leaders of the Bosnian Serb armed forces, as Krstić and Tolimir, were convicted for serious international crimes by the ICTY, but their acts cannot be attributed to a state - see also the Application of the Genocide Convention case).

Third, situations where an international court has found a state responsible for serious human rights and humanitarian law violations, but no criminal proceedings can be, or have been, brought against individual perpetrators (e.g. the Armed Activities case against Uganda for the conduct of its armed forces in the DRC).

In most situations it seems that state responsibility and individual criminal responsibility for mass atrocity crimes is a double necked flask, since atrocities are the product of collective violence, with differing degrees of state involvement. ${ }^{63}$ However, as shown by the three situations above, differences in regimes of international responsibility can lead to instances where a state is held responsible and an individual is not, or vice versa.

\footnotetext{
${ }^{62}$ See inter alia B. Stern, 'The Obligation to Make Reparation', in Crawford, Pellet and Olleson (eds.), The Law of International Responsibility, n. 6, p. 563.

${ }^{63}$ See inter alia Nollkaemper and van der Wilt, System Criminality in International Law, n. 5.
} 
4.3 The interaction between the different regimes of international responsibility for specific mass atrocity crimes

A number of points can be made as to the possible overlap, or disconnection between individual and state responsibility. First, both states and individuals can be responsible for international crimes, and as such share responsibility. In the Application of the Genocide Convention case Serbia and Montenegro had argued that the Genocide Convention was an international criminal law convention focusing essentially on the criminal prosecution and punishment of individuals, and not on the responsibility of states. ${ }^{64}$ In its 2007 judgment, the Court held that:

\begin{abstract}
It is true that the concepts used in paragraphs (b) to (e) of Article III, and particularly that of 'complicity', refer to well known categories of criminal law and, as such, appear particularly well adapted to the exercise of penal sanctions against individuals. It would however not be in keeping with the object and purpose of the Convention to deny that the international responsibility of a State - even though quite different in nature from criminal responsibility - can be engaged through one of the acts, other than genocide itself, enumerated in Article III. ${ }^{65}$
\end{abstract}

A similar overlap also exists for crimes against humanity. The very definition of crimes against humanity necessarily invokes state responsibility, whether through a state's active participation in, or failure to prevent, each crime. ${ }^{66}$ The chapeau elements of common plan or policy requirement for the crime of genocide, and state or organisational policy for crimes against humanity, show the potential close connection between individual criminal responsibility and state responsibility.

Obviously, this shared responsibility only exists to the extent that particular acts indeed are criminalised for individuals. The ICTY Appeals Chamber in the Perišić case considered that assistance from one army to another army's war efforts was insufficient, in itself, to trigger individual criminal liability for individual aid providers, absent proof that the relevant assistance was specifically directed towards criminal activities. ${ }^{67}$

As already noted above, the fact that an individual acts for a state does not preclude its individual responsibility. However, it is unclear when the organisational requirement for the

\footnotetext{
${ }^{64}$ Application of the Genocide Convention, n. 1, at 115, para. 171.

${ }^{65}$ Ibid., at 114, para. 167.

${ }^{66}$ A. Day, 'Crimes Against Humanity as a Nexus of Individual and State Responsibility: Why the ICJ Got Belgium

v. Congo Wrong' (2004) 22 Berkeley Journal of International Law 489, at 491.

${ }^{67}$ Prosecutor v. Momčilo Perišić, ICTY Case No. IT-04-81-A, Appeals Judgment, 28 February 2013, para. 44.
} 
commission of an international crime actually does negate the relevance of attributing individual criminal responsibility for that act. The 1949 Geneva Conventions deny a war criminal's claim that he or she acted as an organ of state, and that his or her behaviour is therefore attributable to the state and not to him or her personally. ${ }^{68}$ However, Spinedi has argued that treating war crimes or crimes against humanity as crimes committed in a 'private capacity' would mean that such crimes cannot be attributed to the state, and as a consequence the state would not be responsible for those acts under international law. ${ }^{69}$

Second, as noted, to the extent that both regimes for responsibility apply, the nature of responsibility is different. The Court observed that the obligations, arising from the terms of the Genocide Convention, and the responsibilities of states that would arise from a breach of such obligations, are 'obligations and responsibilities under international law, and not of a criminal nature'. ${ }^{70}$ It can be added that this as such does not preclude shared responsibility.

Third, in particular in case of heads of states and senior state officials, the responsibility of states and that of such individuals nonetheless is very closely related. In the Taylor case, the Trial Chamber of the SCSL took the extraterritoriality of the crimes into account as an aggravating factor, when stating that "while these provisions of customary law govern conduct between States ... the violation of this principle by a Head of State individually engaging in criminal conduct can be taken into account as an aggravating factor'. ${ }^{71}$ The Appeals Chamber accepted the tenor of this finding by the Trial Chamber, adding that Taylor's acts and conduct did not only harm the victims of the crimes and their immediate relatives, but fuelled a conflict that became a threat to international peace and security in the West African sub-region. ${ }^{72}$ Moreover, the Appeals Chamber noted that Taylor's position as head of state was multifaceted, involving distinct aspects including his leadership role, his further role as a direct participant in the peace process in a position of public trust, and his special status as a head of state who aided and abetted and planned the commission of crimes. ${ }^{73}$ Can these findings be read as the SCSL

\footnotetext{
${ }^{68}$ R. Wolfrum and D. Fleck, 'Enforcement of International Humanitarian Law', in D. Fleck (ed.), The Handbook of International Humanitarian Law (Oxford University Press, 2008), p. 675 at 684.

${ }^{69}$ M. Spinedi, 'State Responsibility v. Individual Responsibility for International Crimes: Tertium Non Datur?' (2002) 13 EJIL 895.

${ }^{70}$ Application of the Genocide Convention, n. 1, at 115, para. 170 (emphasis added).

${ }^{71}$ Prosecutor v. Charles Ghankay Taylor, Sentencing Judgment of 30 May 2012, SCSL Case No. SCSL-03-01-T, para. 27.

${ }^{72}$ Taylor Appeals Judgment, n. 23, para. 683.

${ }^{73}$ Ibid., para. 687.
} 
indirectly engaging the international responsibility of Liberia, acting through its head of state, for crimes committed in Sierra Leone? At a minimum, these findings highlight the special position of heads of states in situations of shared responsibility between states and individuals.

The crime of aggression could be seen as bringing together the notion of 'criminal responsibility' of the state and that of the individual concerned. A state can commit a crime against peace and a political finding to that effect can be made by the United Nations (UN) Security Council, through a resolution adopted under Chapter VII of the UN Charter, ${ }^{74}$ declaring that the conduct of that state threatens international peace and security. At the same time, a state can be found legally responsible by the ICJ for a violation of the UN Charter through the illegal use of force or for rendering support to third parties. ${ }^{75}$ The ICC will most likely be able to exercise jurisdiction over the crime of aggression and prosecute individuals for having started an aggressive war, once Article 8bis enters into force in early $2017 .^{76}$ This Article applies to a person in a position to effectively exercise control over, or to direct, the political or military action of a state.

Fourth, there are relevant differences in the formulation of principles of responsibilities as these apply to states and individuals. For instance, an important distinction is that while proving the subjective element of mens rea or criminal intent is a crucial part of establishing individual criminal responsibility, for purposes of establishing state responsibility that is not necessary. The ILC has taken the position that fault does not constitute a necessary element of the internationally wrongful act of a state, if fault is understood as the existence, for example, of an intention to harm. ${ }^{77}$ An objective, rather than a subjective, test has been endorsed with regard to state responsibility. As a result, it may well happen that in particular cases only states can be held responsible and not individuals or, though more likely, only individuals and not states. In such cases, the different element of responsibility may preclude shared responsibility.

\footnotetext{
${ }^{74}$ Charter of the United Nations, San Francisco, 26 June 1954, in force 24 October 1945, 1 UNTS 16 (UN Charter).

${ }^{75}$ See Nicaragua, n. 33, at 108, para. 205. See also Armed Activities (Democratic Republic of the Congo v. Uganda), n. 20, at 226-227, paras. 162-165.

${ }^{76}$ See Article 8 bis of the ICC Statute (inserted by resolution RC/Res.6 of 11 June 2010). This Article provides that the 'crime of aggression' means the planning, preparation, initiation or execution, by a person in a position effectively to exercise control over or to direct the political or military action of a state, of an act of aggression which, by its character, gravity and scale, constitutes a manifest violation of the UN Charter.

${ }^{77}$ ARSIWA Commentary, n. 51, Commentary to Article 2, para. 10.
} 


\section{Legal processes concerned with international responsibility for mass atrocity crimes}

From an institutional perspective there are several separate legal mechanisms for adjudicating cases involving state or individual responsibility for mass atrocity crimes. The ICJ has dealt with a number of relevant inter-state disputes, ${ }^{78}$ whereas international criminal courts and tribunals such as the ICTY, ICTR and ICC have prosecuted a number of individuals, focusing mainly on high-level perpetrators bearing the greatest responsibility.

Legal processes concerning state and individual criminal responsibility for mass atrocity crimes have taken place at both the domestic and the international level. Domestic courts have mainly addressed alleged perpetrators, ${ }^{79}$ and in rare cases also have dealt with issues of state responsibility. ${ }^{80}$ The ICTY and domestic courts in the former Yugoslavia have prosecuted perpetrators of mass atrocity crimes committed during the Balkan wars. The ICJ has dealt with the genocide case in Bosnia, as well as with a number of other cases arising from those armed conflicts. The ICTR and domestic courts in Rwanda have prosecuted perpetrators of the mass atrocities committed in Rwanda in 1994. Domestic courts in Greece and Italy have dealt with cases against Germany for violations of human rights and humanitarian law during WW2. The ICJ has dealt with this latter situation in terms of adjudicating whether these foreign domestic courts could hold Germany responsible in its 2012 decision in the Jurisdictional Immunities case. ${ }^{81}$ These are examples of legal processes aimed at addressing mass atrocities, which expose

\footnotetext{
${ }^{78}$ See inter alia Nicaragua, n. 33; Legality of Use of Force cases (see 'List of All Cases' at www.icj-cij.org); Armed Activities (Democratic Republic of the Congo v. Uganda), n. 20; Armed Activities on the Territory of the Congo (New Application: 2002) (Democratic Republic of the Congo v. Rwanda), n. 32; Application of the Genocide Convention, n. 1; Jurisdictional Immunities of the State (Germany v. Italy: Greece intervening), Judgment, ICJ Reports 2012, p. 99; Obligation to Prosecute or Extradite, n. 30.

${ }^{79}$ For a detailed discussion see inter alia W.N. Ferdinanduse, Direct Application of International Criminal Law in National Courts (The Hague: TMC Asser Press, 2006). See also, A. Cassese, Cassese's International Criminal Law, 3rd edn (Oxford University Press, 2013), pp. 271-308. The preamble to the ICC Statute, n. 52, provides that 'the most serious crimes of concern to the international community as a whole must not go unpunished and ... their effective prosecution must be ensured by taking measures at the national level and by enhancing international cooperation'. This wording effectively acknowledges that international criminal justice, including the ICC system, where victims are allowed to participate and get reparations, is limited in its ability to address mass atrocities and therefore domestic courts have a very important role to play.

${ }^{80}$ See inter alia Ferrini v. Federal Republic of Germany, Decision No. 5044/2004 in (2004) 87 Rivista di diritto internazionale 539; Prefecture of Voiotia v. Federal Republic of Germany, Case No. 11/2000, 129 ILR 513 (2000) (Distomo case).

${ }^{81}$ Jurisdictional Immunities of the State, n. 78.
} 
the uneasy relationship between state responsibility and individual criminal responsibility, as well as the considerable limitations of these legal processes.

Four points in particular should be made in relation to the co-existence of these procedures. First, in principle these legal processes are independent and therefore not contingent on each other. In terms of the chronological relationship of processes concerned with finding responsibility, the ICJ has found that '[s]tate responsibility can arise under the Convention for genocide and complicity, without an individual being convicted of the crime or an associated one'. ${ }^{82}$ Through this finding the Court not only has acknowledged the different international legal mechanisms in place for determining state responsibility and individual criminal responsibility, as well as the independent nature of their work, but also that different situations with regard to international responsibility might occur. While the issue of chronological order might not be an issue for genocide, war crimes or crimes against humanity, for the crime of aggression it seems necessary to first have a finding on state responsibility, before prosecuting an individual for that crime. That has to do with the nature of the crime of aggression, as an act of illegal use of force by a state with serious consequences for international peace and security.

Second, while these international judicial mechanisms operate independently and there is no formal hierarchy in place, in practice there has been considerable cross-referencing to each-others' decisions. ${ }^{83}$ With very few exceptions, ${ }^{84}$ most of this interaction has taken place in a spirit of comity and constructive dialogue.

Third, from an operational perspective there are differences concerning access to, the triggering of jurisdiction, and legal procedures before these institutions. The institutional limitations of these international judicial bodies and the fluctuating levels of state cooperation and political and other support from the international community have resulted in varied levels of accountability for mass atrocities in different situations. Notably, the existence of barriers of

\footnotetext{
${ }^{82}$ Application of the Genocide Convention, n. 1, at 120, para. 182.

${ }^{83}$ See inter alia G. Zyberi, The Humanitarian Face of the International Court of Justice (Antwerp: Intersentia, 2008), pp. 343-84. The ICJ has made ample use of the findings of the ICTY in its 2007 and 2015 judgments in Application of the Genocide Convention brought respectively by Bosnia and Hercegovina and by Croatia against Serbia. At the same time, a number of accused at the ICTY have demanded that the legality of the establishment of the ICTY be brought before the ICJ, though without success.

${ }^{84}$ Notable exceptions are the different positions of the ICTY and the ICJ on the issue of control for a finding of state responsibility for actions of third parties (namely the test of 'overall' or 'effective' control, respectively in Tadic and the Application of the Genocide Convention) and the ICTY and the SCSL on the issue of specific direction (Appeals Chamber's decisions respectively in Perišić and Taylor).
} 
a jurisdictional nature, combined with the lack of political will or other pragmatic reasons, has resulted in situations where only state or individual responsibility has been pursued, even when concurrence between the two forms of responsibility has been fairly obvious.

Given that state consent and state cooperation are necessary preconditions to support legal processes concerning both state responsibility and individual criminal responsibility, the capacity, attitude and conduct of state authorities can greatly influence the outcome of these international legal processes. ${ }^{85}$ At times states have withheld relevant evidence on grounds of national security, have threatened to stop or have stopped cooperation for a period of time, or have refrained from detaining and surrendering persons accused by international (criminal) courts and tribunals. Most recently, lack of state cooperation was cited as an important factor in the ICC Prosecutor's decision to withdraw the charges in two cases related to the situation in Kenya ${ }^{86}$ Lack of state cooperation and action by the Security Council led the ICC Prosecutor to the decision to hibernate investigations with regard to the situation in Darfur, Sudan. ${ }^{87}$ State cooperation seems to largely depend on whether the indicted persons are part of the elite ruling the country and the strength of their power-base, as well as on the extent of international pressure.

A particularly relevant barrier to adjudication, especially before foreign domestic jurisdictions, is the principle of state immunity and its corollary, namely immunity of senior state officials. There have been attempts to use the principle of immunity as an excuse for escaping individual criminal responsibility. Thus, Slobodan Milošević (President of Serbia when publicly indicted by the ICTY) and Charles Taylor (President of Liberia when indicted, under seal, by the SCSL) attempted to use their official status to claim immunity from

\footnotetext{
${ }^{85}$ See chapter 9 in this volume, G. Sluiter, 'International Criminal Tribunals and their Relation to States', __.

${ }^{86}$ Prosecutor v. Francis Kirimi Muthaura and Uhuru Muigai Kenyatta, ICC Case No. ICC-01/09-02/11, Prosecution notification of withdrawal of the charges against Francis Kirimi Muthaura, 11 March 2013, para. 11, available at www.icc-cpi.int/iccdocs/doc/ICC-01-09-02-11-687.pdf. In withdrawing the charges against $\mathrm{Mr}$ Muthaura the Prosecution noted the fact of only limited cooperation provided by the Government of Kenya to the Prosecution as having weighed on the latter's decision to withdraw the charges in this case. On 13 March 2015, the ICC withdrew the charges against Mr Kenyatta, see The Prosecutor v. Uhuru Muigai Kenyatta, ICC Case no. ICC-01/09-02/11, 'Decision on the withdrawal of charges against Mr Kenyatta', 13 March 2015.

${ }^{87}$ Prosecutor of the International Criminal Court, 'Statement to the United Nations Security Council on the Situation in Darfur, pursuant to UNSCR 1593 (2005)', 12 December 2014, para. 4.
} 
prosecution. ${ }^{88}$ In August 2003, Liberia even sought to bring proceedings before the ICJ against Sierra Leone in respect of a dispute concerning the indictment and international arrest warrant of 7 March 2003, issued against Taylor, by a decision of the SCSL at Freetown. ${ }^{89}$ Sierra Leone did not consent to the jurisdiction of the ICJ. ${ }^{90}$ So far, attempts to evade individual criminal responsibility based on the official status of the accused have been unsuccessful in international criminal proceedings.

At the same time, the defence of immunity has proved successful in thwarting domestic criminal proceedings against incumbent heads of state, or of governments and other senior state officials. In the Arrest Warrant case, the ICJ found that the issue of an arrest warrant against the incumbent Minister for Foreign Affairs of the DRC and its international circulation, constituted violations of a legal obligation of Belgium towards the DRC, in that they failed to respect the immunity from criminal jurisdiction and the inviolability which Mr Ndombasi enjoyed under international law. ${ }^{91}$ However, the Court also noted that:

\footnotetext{
The immunity from jurisdiction enjoyed by incumbent Ministers for Foreign Affairs does not mean that they enjoy impunity in respect of any crimes they might have committed, irrespective of their gravity. Immunity from criminal jurisdiction and individual criminal responsibility are quite separate concepts. While jurisdictional immunity is procedural in nature, criminal responsibility is a question of substantive law. Jurisdictional immunity may well bar prosecution for a certain period or for certain offences; it cannot exonerate the person to whom it applies from all criminal responsibility. ${ }^{92}$
}

A similar case was initiated before the ICJ in 2002 by the Congo against France for certain criminal proceedings French authorities had started against the Congolese President, Denis Sassou Nguesso, and a number of high officials, but ultimately this case was discontinued in

\footnotetext{
${ }^{88}$ See Prosecutor v. Charles Ghankay Taylor, Case No. SCSL-2003-01-I, Decision on Immunity from Jurisdiction, 31 May 2004.

89 'Liberia applies to the International Court of Justice in a dispute with Sierra Leone concerning an international arrest warrant issued by the Special Court for Sierra Leone against the Liberian President', ICJ Press Release 2003/26, 5 August 2003.

${ }^{90}$ See Arrest Warrant of 11 April 2000 (Democratic Republic of the Congo v. Belgium), Judgment, ICJ Reports 2002, p. 3 (Arrest Warrant).

${ }^{91}$ Ibid., p. 33, para. 78(2).

${ }^{92}$ Ibid., p. 25, para. 60 (emphasis in original).
} 
$2010 .{ }^{93}$ The topic of immunity of state officials from foreign criminal jurisdiction has been included in the agenda of the ILC. ${ }^{94}$ There seems to be general agreement and sufficient state practice that incumbent heads of states enjoy immunity from domestic criminal prosecution in other states.

The defence of state immunity has been used to thwart domestic proceedings in foreign domestic courts concerning the granting of reparations for violations of human rights and humanitarian law. In February 2012, the ICJ found Italy in violation of its obligation to respect the immunity which Germany enjoyed under international law, by allowing civil claims to be brought against it based on violations of international humanitarian law committed by the German Reich between 1943 and 1945, ${ }^{95}$ as well as by declaring enforceable in Italy decisions of Greek courts based on violations of international humanitarian law committed in Greece by the German Reich. ${ }^{96}$ Moreover, the Court found neither a basis in state practice that international law made the entitlement of a state to immunity dependent upon the existence of effective alternative means of securing redress for victims, nor a provision to such effect in relevant treaties. ${ }^{97}$ While according to the Court the question whether Germany still has a responsibility towards Italy, or individual Italians, in respect of war crimes and crimes against humanity committed by it during WW2 did not affect Germany's entitlement to immunity, the Court noted that a solution to this issue could be negotiated by the parties. ${ }^{98}$ Through these findings, the ICJ has practically removed a potentially important venue where victims of mass atrocity crimes can ask for redress for past wrongs.

\section{Concluding remarks}

When it comes to mass atrocity crimes states and individuals are bound by similar obligations, which have a strong basis in both treaty law and in customary international law. In principle, all states and individuals are bound by these legal obligations due to their customary nature.

\footnotetext{
${ }^{93}$ Certain Criminal Proceedings in France (Republic of the Congo v. France), Order of 16 November 2010, ICJ Reports 2010, p. 635.

${ }^{94}$ For more information on the work of the ILC on this topic see http://legal.un.org/ilc/guide/4_2.htm. See especially ILC Report, UN Doc. A/69/10 (2014), ch. IX, paras. 123-132.

95 Jurisdictional Immunities of the State, n. 78, para. 139(1).

${ }^{96}$ Ibid., para. 139(3).

${ }^{97}$ Ibid., para. 101.

${ }^{98}$ See ibid., paras. 104 and 108.
} 
Nevertheless, the scope of such obligations imposed on states and individuals by primary rules of international law which embody commonly shared values and interests is not the same. Breaches of these fundamental legal norms lead to international responsibility. Due to the serious nature of such crimes, in principle, both states and individuals can be responsible for the same situation. However, differences in the international legal regime of responsibility can lead to situations where a state is held responsible and an individual escapes responsibility, or vice versa.

A number of reasons of a political or legal nature inform and influence the conduct of relevant stakeholders which might result in an accountability gap for mass atrocities, be it in terms of state responsibility or individual criminal responsibility. Moreover, various levels of accountability are achieved for situations where mass atrocity crimes have been committed, because the available legal mechanisms for adjudicating the responsibility of states or of individuals have different triggering mechanisms, jurisdictional scope, and operate separately and independently of each-other. At present, international law employs different legal concepts and mechanisms for deciding on the responsibility of individuals or of states that have violated international norms which denote protected community interests, some of which enjoy the status of jus cogens.

The difficulty of applying a traditional criminal law approach based on individual criminal responsibility especially to situations which are essentially collective, both in their perpetration and their consequences, is fairly obvious. The dire situation in Syria, with serious crimes committed by all parties to the armed conflict, that is, by Syrian government armed forces and by non-state armed groups (especially ISIL), aided by ongoing support from third states is an example of a collective failure to prevent and stop mass atrocities. As Bonafè has pointed out, the rapid development of international criminal law and its increasing focus on mass atrocities and state leaders' liability have significantly brought to the surface the problems connected with the overlap between state and individual responsibility for the same crimes. ${ }^{99}$ The case law of the ICTY, the ICTR, and the ICC concerning individual criminal responsibility and that of the ICJ concerning state responsibility has struggled with many of these conceptual problems, resulting in the further development of international law. Pellet seems to have rethought to some extent his initial position in favour of the criminal responsibility of the

\footnotetext{
${ }^{99}$ Bonafè, The Relationship Between State and Individual Responsibility for International Crimes, n. 7, p. 253.
} 
state. ${ }^{100}$ Subsequently he has argued that the penal elements, which are more apparent in the case of violations of a class of international obligations 'so essential for the protection of fundamental interests of the international community', are not sufficient to change the nature of international responsibility as a whole, nor even to conclude that the regime of aggravated responsibility is in truth of a penal nature. ${ }^{101}$ In his view, the ILC was correct to abandon the misleading vocabulary of criminal law.

It is clear that drawing an analogy between individual criminal responsibility (and that of legal persons) in municipal law and a state's international responsibility for a 'crime' (or for the violation of certain international obligations) leads to a number of theoretical and practical difficulties, and calls into question the very structure of the international society. ${ }^{102}$ Ollivier notes that on a practical level the emergence of a criminal responsibility of states is not impossible. ${ }^{103}$ As he points out, through saving clauses the ARSIWA do not prejudge future developments, as these Articles were adopted 'without prejudice' to other specific consequences of serious breaches of peremptory norms (Article 41(3) ARSIWA), and to the lawful measures that states other than an injured state may take (Article 54 ARSIWA). ${ }^{104}$ Jørgensen has argued that the principle of state criminality is an emergent general principle of international law, which may also be described as an emerging category of customary international law. ${ }^{105}$ While international judicial bodies are important for ensuring state and individual criminal responsibility for mass atrocities in their aftermath, it is important not to lose sight of the fact that political mechanisms at the international and the regional level offer venues which are much more flexible and suitable to address situations of conflict. These political mechanisms operating alongside the international judicial bodies can, and should, be used to compensate for the deficiencies of the international legal system.

A closer look at secondary rules concerning mass atrocity crimes shows a close connection between individual criminal responsibility and state responsibility, but at the same time also reveals a number of necessary conceptual differences. At the normative level, while

\footnotetext{
${ }^{100}$ See A. Pellet, 'Can a State Commit a Crime? Definitely, Yes!' (1999) 10(2) EJIL 425.

${ }^{101}$ A. Pellet, 'The Definition of Responsibility in International Law' in Crawford, Pellet and Olleson (eds.), The Law of International Responsibility, n. 6, p. 3, at 14.

102 Ollivier, 'International Criminal Responsibility of the State', n. 7, p. 704.

103 Ibid., p. 713.

104 Ibid.

105 Jørgensen, The Responsibility of States for International Crimes, n. 7, pp. 279-280.
} 
practice before international judicial mechanisms has hammered out most of the secondary rules concerning attribution of responsibility and legal consequences, some of them still remain highly debatable. At the enforcement level, despite the ground-breaking institutional developments of the late $20^{\text {th }}$ century, there remains an obvious imbalance between the normative content and obligations imposed on states and individuals by primary rules, and the possibility to enforce them. Moreover, without the necessary political commitment and state cooperation, the enforcement of these primary rules on mass atrocity crimes risks remaining an empty promise. The situation of Syria, Libya, Democratic Republic of Congo, Central African Republic, Darfur (Sudan), Ukraine, Myanmar, Afghanistan and other states show that shared responsibility for preventing or stopping mass atrocity crimes might result in a diluted sense of responsibility and lack of accountability for failures. Seemingly, international judicial mechanisms created to deal with mass atrocity situations are bound to face an uphill struggle in upholding the high standards of international justice, while trying to live up to the great expectations placed upon them. 